\title{
PENGARUH SISTEM OLAH TANAH PADA LAHAN ALANG-ALANG (Imperata cylindrica) TERHADAP BIOMASSA KARBON MIKROORGANISME TANAH (C-mik) YANG DITANAMI KEDELAI (Glycine max L.) MUSIM KE DUA
}

\author{
Yurres Satrio Wibowo, Henrie Buchari, M. A. Syamsul Arif \& Muhajir Utomo \\ Jurusan Agroteknologi, Fakultas Pertanian Universitas Lampung \\ Jl. Prof. Soemantri Brodjonegoro, No. 1, Bandar Lampung 35145 \\ E-mail: yurres.satrio.wibowo@gmail.com
}

\begin{abstract}
ABSTRAK
Penelitian ini bertujuan untuk mengetahui pengaruh sistem olah pada lahan alang-alang (Imperata cylidrica) terhadap biomassa karbon mikroorganisme tanah (C-mik) yang ditanami kedelai (Glycine max $\mathrm{L}$ ) musim ke dua. Penelitian ini dilakukan dengan menggunakan rancangan acak kelompok (RAK) dengan perlakuan 3 sistem olah tanah, TOT = Tanpa Olah Tanah, OTM = Olah Tanah Minimum, OTI = Olah Tanah Intensif, dengan 6 kali ulangan. Sampel tanah diambil sebelum olah tanah $\left(\mathrm{W}_{0}\right)$, satu hari setelah olah tanah $\left(\mathrm{W}_{1}\right)$, masa vegetatif maksimum $\left(\mathrm{W}_{2}\right)$, dan panen $\left(\mathrm{W}_{3}\right)$. Tanaman kedelai digunakan sebagai indikator respon perlakuan yang diterapkan. Data yang diperoleh diuji homogenitasnya, dengan uji Bartlett dan aditifitas diuji dengan uji tukey. Data dianalisis dengan sidik ragam dan dilanjutkan dengan Uji BNT 5\%. Berdasarkan hasil uji BNT pada taraf 5\%, sistem olah tanah masa panen tanaman kedelai (Glycine max L.) nyata dalam mempengaruhi kapasitas tukar kation (KTK).
\end{abstract}

Kata kunci: alang-alang (Imperata cylidrica), biomassa karbon mikroorganisme tanah (C-mik), kedelai (Glycine max L), sistem olah tanah

\section{PENDAHULUAN}

Lahan alang-alang (Imperata cylindrica) merupakan salah satu lahan yang berpotensial untuk peningkatan produksi pertanian khususnya tanaman pangan. Di lampung luas lahan alang-alang sekitar 75.921 hektar, artinya jika lahan tersebut dapat dimanfaatkan dengan baik tentunya peningkatan produksi pertanian akan lebih optimal. Hilangnya fungsi produksi dari sumber daya tanah dapat terus menerus diperbaharui, karena diperlukan waktu puluhan bahkan ratusan tahun untuk pembentukan tanah tersebut (Hasnudi dan Eniza, 2004), sehingga untuk pemanfaatan lahan alang-alang diperlukan sistem pengolahan tanah yang tepat. Beberapa hasil penelitian menunjukkan bahwa pengolahan tanah yang berlebihan menjadi penyebab utama terjadinya kerusakan struktur tanah. Sehingga diperlukan suatu sistem olah tanah yang lebih rasional terhadap kelestraian lingkungan (Rachman dkk., 2003).

Olah tanah konservasi (OTK) menjadi salah satu alternatif pengolahan tanah yang tetap mempertahankan produktivitas tanah yang tinggi. Olah tanah konservasi (OTK) adalah cara penyiapan lahan yang menyisakan sisa tanaman di atas permukaan tanah sebagai mulsa dengan tujuan untuk mengurangi erosi dan mengurangi penguapan air dari permukaan tanah. Selain sistem olah tanah, keberadaan bahan organik tanah memegang peranan penting pada pertumbuhan tanaman. Hal ini mengingat bahwa bahan organik tanah dapat mengendalikan berbagai proses penting dalam tanah, seperti memasok hara melalui perubahan status $\mathrm{C}$ dan $\mathrm{N}$ sebagai unsur utama bahan organik tanah, meningkatkan agregasi tanah, meningkatkan ketersediaan air tanah, dan mengurangi kehilangan hara tanah (Utomo, 1995).

C-mik dapat digunakan sebagai indikator kesuburan tanah karena tingginya mikroorganisme tanah hanya mungkin terjadi jika tanah tersebut mempunyai sifat yang mendukung aktifitas dan perkembangan mikroorganisme tanah. Penelitian ini bertujuan untuk mengetahui pengaruh sistem olah pada lahan alang-alang (Imperata cylidrica) terhadap biomassa karbon mikroorganisme tanah (C-mik) yang ditanami kedelai (Glycine $\max$ L.) musim kedua.

\section{BAHAN DAN METODE}

Penelitian ini dilaksanakan pada bulan juli 2012 sampai dengan bulan oktober 2012 di daerah Blora Indah kelurahan Segala Mider, Tanjung Karang Barat, Bandar Lampung. Alat-alat yang digunakan dalam pengambilan 
contoh tanah di lapang adalah bor tanah, cangkul, kantung plastik, meteran, soil moisture tester (mengukur kelembaban tanah), temperature (mengukur suhu tanah) dan spidol. Alat yang dipergunakan di laboratorium adalah kulkas, oven, ayakan $2 \mathrm{~mm}$, toples plastik ukuran 1 liter, botol film, pH meter, labu ukur $1000 \mathrm{ml}$, stand buret, buret $50 \mathrm{ml}$, desikator, alumunium foil, pipet tetes $10 \mathrm{ml}$, corong, timbangan, lakban, desikator, kompresor, erlenmeyer $250 \mathrm{ml}$ dan gelas piala $50 \mathrm{ml}$.

Bahan-bahan yang digunakan dalam penelitian ini adalah contoh tanah dari daerah Blora Indah kelurahan segala mider Tanjung Karang Barat Bandar Lampung, aquades, $\mathrm{KOH} 0,5 \mathrm{~N}, \mathrm{HCl}$, kloroform, phenophtalein, metil orange, butir-butir batu didih (pecahan keramik), kertas tisu, pupuk kimia (Urea, SP-18 dan KCl), benih kedelai Tanggamus, dan herbisida glifosat. Penetapan biomassa karbon mikroorganisme (C-mik) tanah dilakukan dengan metode fumigasi dan inkubasi (Jenkinson and Powlson, 1976), C-organik (Walkey and Black), dan $\mathrm{pH}$ tanah (metode elektrometrik).

\section{BAHAN DAN METODE}

Penelitian ini dilakukan dengan menggunakan rancangan acak kelompok (RAK) yang terdiri atas 3 (tiga) perlakuan dan 6 (enam) ulangan, sehingga diperoleh 18 (delapan belas) satuan petak percobaan. Perlakuan yang diterapkan dalam penelitian ini adalah $\mathrm{T}_{0}=$ Tanpa Olah Tanah (TOT), $\mathrm{T}_{1}=$ Olah Tanah Minimum (OTM), dan $\mathrm{T}_{2}=$ Olah Tanah Intensif (OTI). Pada masing-masing petak percobaan, sampel tanah diambil pada lima titik kemudian dikompositkan.

Pengambilan sampel tanah dilakukan sebelum pengolahan tanah $\left(\mathrm{W}_{0}\right)$, satu hari setelah olah tanah $\left(\mathrm{W}_{1}\right)$, masa fase vegetatif maksimum $\left(\mathrm{W}_{2}\right)$ dan panen $\left(\mathrm{W}_{3}\right)$. Penelitian ini dilaksanakan pada lahan alang-alang yang berumur lebih dari 10 tahun. Selama 10 tahun, pengelolaan dilakukan hanya dengan memotong alangalang setiap dua sampai empat minggu sekali dan serasahnya dibiarkan hingga menjadi bahan organik. Lahan tersebut belum pernah dilakukan pengolahan tanah dan penanaman tanaman, hingga penelitian periode satu pada tahun 2010 dengan menggunakan tanaman jagung. Sehingga Dilakukan penelitian lanjutan musim kedua dengan menggunakan tanaman kedelai (Glycine $\max$ L.).

Sampel tanah diambil dengan menggunakan bor tanah dari lokasi penelitian. Contoh tanah diambil sebanyak lima titik setiap ulangan, sampai kedalaman $20 \mathrm{~cm}$ disetiap titik pengambilan. Kemudian contoh tanah yang diambil pada setiap titik dikompositkan berdasarkan ulangan. Pengambilan sampel awal dilakukan sebelum pengolahan lahan $\left(\mathrm{W}_{0}\right)$, pengambilan sampel tanah kedua, setelah satu hari setelah olah tanah $\left(\mathrm{W}_{1}\right)$, pengambilan sampel ketiga pada fase vegetatif maksimum $\left(\mathrm{W}_{2}\right)$ dan pengambilan sampel keempat dilakukan saat panen $\left(\mathrm{W}_{3}\right)$.

Pada saat dua minggu sebelum pelaksanaan penelitian dilakukan pengukuran lahan dan pembuatan plot percobaan. Plot percobaan dibuat secara kelompok, tiga perlakuan dan enam ulangan. Pada petak olah tanah intensif (OTI), pengolahan tanah dimulai dengan pembabatan alang-alang, kemudian tanah diolah sebanyak 2 kali. Mula-mula tanah dicangkul sedalam lebih kurang $20 \mathrm{~cm}$ secara merata, kemudian dilakukan penghancuran bongkahan pertama. Tanah diratakan dan sisa alang-alang dibuang dikeluarkan dari petak percobaan.

Pada olah tanah minimum (OTM) lahan tidak disemprot menggunakan herbisida tetapi hanya dilakukan pembabatan gulma, dan pengolahan tanah seperlunya yaitu hanya setebal $10 \mathrm{~cm}$, kemudian sisa tanaman gulma (alang-alang) digunakan sebagai mulsa. Sedangkan pada petak tanpa olah tanah (TOT), pengolahan tanah tidak dilakukan, namun dilakukan pembuatan lubang tanam untuk peletakan benih. Selanjutnya gulma yang tumbuh, dikendalikan dengan menggunakan herbisida, kemudian sisa gulma dikembalikan ke lahan sebagai mulsa.

Variabel Pengamatan Utama. Proses pelaksanaan analisis yaitu $100 \mathrm{~g}$ tanah lembab ditempatkan dalam gelas beaker $50 \mathrm{ml}$. Tanah tersebut kemudian difumigasi menggunakan kloroform $\left(\mathrm{CHCl}_{3}\right)$ sebanyak $30 \mathrm{ml}$ dalam desikator yang telah diberi tekanan $50 \mathrm{~cm} \mathrm{Hg}$ selama 48 jam. Sebanyak 10 gram tanah inokulan diikat rapat dalam plastik kemudian dimasukkan ke dalam lemari pendingin. Setelah tanah difumigasi selama 48 jam, katup desikator dibuka untuk mengeluarkan sisa kloroform. Setelah itu setiap contoh tanah dimasukkan ke dalam toples berukuran 1 liter bersama dua botol film, satu botol berisi $10 \mathrm{ml} \mathrm{KOH} \mathrm{0,5} \mathrm{N}$ dan satu botol selanjutnya berisi $10 \mathrm{ml}$ aquades. Kemudian ditambahkan $10 \mathrm{~g}$ tanah inokulan (tanah segar) yang telah dikeluarkan dari lemari pendingin pada saat pertama fumigasi. Setelah dikeluarkan dari lemari pendingin, tanah tersebut didiamkan selama kurang lebih 30 menit (proses aklimatisasi). Toples tersebut kemudian ditutup sampai kedap udara dengan menggunakan lakban dan diinkubasi pada suhu $25^{\circ} \mathrm{C}$ ditempat gelap selama 10 hari. Kuantitas $\mathrm{C}-\mathrm{CO}_{2}$ yang diserap dalam alkali ditentukan dengan titrasi (Anderson, 1982 dalam Franzluebbers, 1995). Pada akhir inkubasi, ditambahkan indikator phenophtalein sebanyak 2 tetes pada beaker berisi $\mathrm{KOH}$ dan dititrasi dengan $\mathrm{HCl} 0,1 \mathrm{~N}$ hingga warna 
merah hilang. Jumlah $\mathrm{HCl}$ yang ditambahkan dicatat, selanjutnya dititrasi lagi dengan $\mathrm{HCl}$ setelah ditambahkan 2 tetes metil orange hingga warna kuning berubah menjadi merah muda. Sedangkan untuk blangko menggunakan $100 \mathrm{~g}$ tanah berat kering oven. Tanah tersebut dimasukkan ke dalam toples berukuran 1 liter

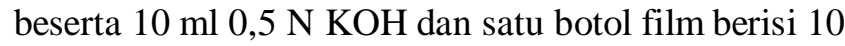
$\mathrm{ml}$ aquades, tetapi tidak diberikan inokulan.

Variabel pendukung yang diamati pada akhir $( \pm 115$ hari) adalah analisis C-organik (metode Walkley dan Black dalam Thom dan Utomo, 1990), reaksi tanah/pH (metode elektrometrik), suhu tanah $\left({ }^{\circ} \mathrm{C}\right)$ (alat soil temperature), kelembaban tanah (\%) (alat soil moisture tester), dan kapasitas tukar kation $\left(\mathrm{cmol}(+) \mathrm{kg}^{-1}\right)$. Data yang diperoleh diuji dengan menggunakan analisis ragam. Sebelum analisis ragam, homogenitas data diuji dengan uji barlet dan aditifitas data dengan uji tukey, kemudian dilakukan juga uji korelasi antara variabel utama dengan variabel pendukung. Setelah itu dilakukan uji lanjut dengan uji Beda Nyata Terkecil (BNT) taraf $5 \%$.

\section{HASIL DAN PEMBAHASAN}

Pengaruh sistem olah tanah terhadap biomassa karbon mikroorganisme tanah (C-mik) (Tabel 1), tidak memberikan pengaruh nyata pada sebelum olah tanah $\left(\mathrm{W}_{0}\right)$, satu hari setelah pengolahan tanah $\left(\mathrm{W}_{1}\right)$, masa vegetatif maksimum $\left(\mathrm{W}_{2}\right)$ maupun masa panen $\left(\mathrm{W}_{3}\right)$. Hal ini diduga, pemberaan selama satu tahun setelah penelitian sebelumnya memberikan akumulasi bahan organik yang seragam terhadap perlakuan sitem olah tanah baik tanpa olah tanah (TOT), olah tanah minimum (OTM) maupun olah tanah intensif (OTI). Walaupun sistem olah tanah berbeda, jumlah biomassa karbon mikroorganisme tanah (C-mik) belum menunjukkan perbedaan yang signifikan tiap perlakuan olah tanah karena proses dekomposisi yang terjadi di dalam tanah oleh mikroorganisme diduga lambat dengan masih belum selesainya proses dekomposisi bahan organik.

Hal ini juga terjadi pada sistem olah tanah konservasi (OTK), yaitu tanpa olah tanah (TOT) dan olah tanah minimum (OTM). Penyiraman yang dilakukan setiap hari satu kali pada sore hari, hal ini diduga menyebabkan keseragaman suhu dan kelembaban, sehingga pengaruh sistem olah tidak berpengaruh nyata terhadap aktivitas mikroorganisme tanah. Dengan demikian, maka biomassa karbon mikroorganisme tanah (C-mik) memberikan hasil yang sama untuk setiap perlakuan. Selain itu, jumlah biomassa yang tidak nyata diduga periode aklimatisasi dari suhu lemari pendingin ke suhu kamar hanya dua jam, sehingga aktivitas mikroorganisme tanah masih belum optimal untuk mulai mensintesis bahan organik. Periode aklimatisasi yang baik yaitu satu hari dari suhu lemari pendingin ke suhu kamar, hal ini dimaksudkan agar kondisi mikroorganisme kembali normal setelah disimpan dari lemari pendingin (Kirana, 2011).

Berdasarkan hasil pengamatan biomassa karbon mikroorganisme tanah (C-mik) (Gambar 1), pada sebelum olah tanah, satu hari setelah pengolahan tanah ke masa vegetatif maksimum, mengalami peningkatan. Hal ini diduga karena pengaruh vegetasi tanaman yang berada pada vase vegetatif maksimum juga mempengaruhi meningkatnya $\mathrm{CO}_{2}$ tanah yang berasal dari eksudat akar yang meningkat dan semakin tinggi jumlah biomassa karbon mikroorganisme tanah maka jumlah bahan organik yang disintesis semakin tinggi juga, sehingga dapat menghasilkan unsur hara yang dapat digunakan untuk tanaman.

Pada masa vegetatif maksimum, biomassa karbon mikroorganisme tanah (C-mik) tertinggi terdapat pada sistem tanpa olah tanah (TOT), tetapi mengalami penurunan dibandingkan pada masa satu hari sebelum panen. Hal ini diduga kandungan bahan organik dalam

Tabel 1. Ringkasan hasil analisis ragam pengaruh sistem olah tanah pada lahan alang-alang terhadap biomassa karbon mikroorganisme tanah (C-mik) yang ditanami kedelai (Glycine max L.)

\begin{tabular}{|c|c|c|c|c|}
\hline \multirow[t]{3}{*}{ Perlakuan } & \multicolumn{4}{|c|}{ Waktu Pengamatan } \\
\hline & Sebelum Olah & Setelah Olah & Vegetatif Maksimum & Panen \\
\hline & \multicolumn{4}{|c|}{ 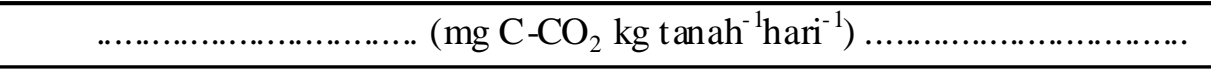 } \\
\hline $\mathrm{T}_{0}$ & tn & tn & tn & tn \\
\hline $\mathrm{T}_{1}$ & tn & tn & tn & tn \\
\hline $\mathrm{T}_{2}$ & tn & $\operatorname{tn}$ & tn & tn \\
\hline
\end{tabular}

Keterangan : th $=$ tidak nyata pada $\alpha=0,05 . \mathrm{T}_{0}=$ tanpa olah tanah, $\mathrm{T}_{1}=$ olah tanah minimum, $\mathrm{T}_{2}=$ olah tanah intensif. 


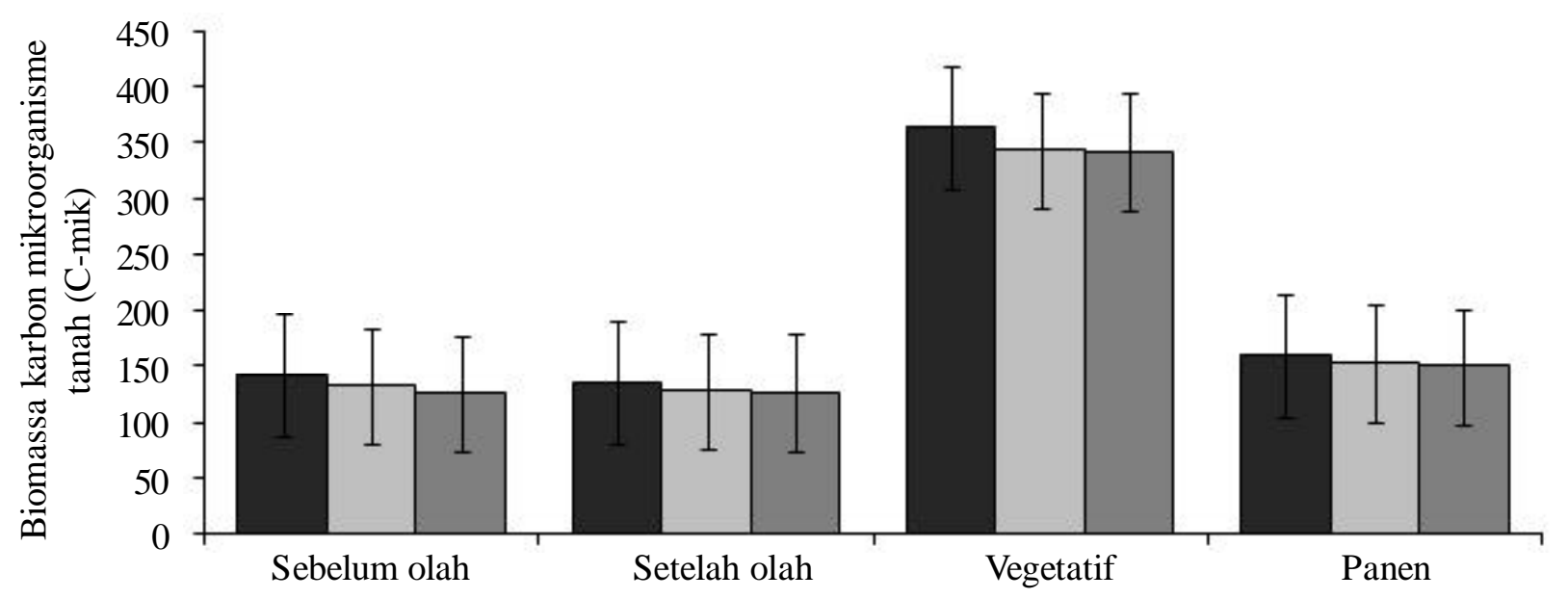

Gambar 1. Pengaruh sistem olah tanah pada lahan alang-alang terhadap biomassa karbon mikroorganisme tanah (C-mik) yang ditanami kedelai (Glycine max $\mathrm{L}$.) pada sebelum pengolahan tanah $\left(\mathrm{W}_{0}\right)$, satu hari setelah olah tanah $\left(\mathrm{W}_{1}\right)$, masa vegetatif $\left(\mathrm{W}_{2}\right)$, dan panen $\left(\mathrm{W}_{3}\right)$. $\square=$ TOT, $\square=$ OTM, dan $\mathbf{\square}=$ OTI.

tanah telah berkurang karena digunakan untuk aktifitas mikroorganisme. Bahan organik merupakan sumber energi bagi mikroorganisme tanah, sehingga semakin banyak bahan organik maka akan meningkatkan populasi mikroorganisme yang akan berakibat terhadap peningkatan aktivitas mikroorganisme tanah (Nursyamsi $d k k .$, 1996).

Sedangkan pada sistem olah tanah intensif (OTI) terjadi aerasi dan drainase tanah yang tinggi, sehingga unsur hara di dalam tanah mudah tercuci atau habis. Raguan (2009) melaporkan, pada perlakuan pengolahan tanah intensif tidak terdapat perbedaan biomassa karbon mikroorganisme tanah (C-mik) pada daerah rizosfir maupun non-rizosfir. Hal tersebut diduga karena telah terjadi pencucian hara yang dibutuhkan oleh mikroorganisme tanah untuk berkembang dan melakukan aktivitasnya.

Sistem olah tanah pada masa panen nyata dalam mempengaruhi kapasitas tukar kation (KTK) (Tabel 2). Hal ini diduga karena pemberaan selama satu tahun setelah penelitian sebelumnya dan seluruh lahan hanya ditumbuhi gulma alang-alang, sehingga pengolahan tanah secara konservasi maupun secara konvensional terdapat bahan organik yang mempengaruhi kapasitas tukar kation didalam tanah. Arifin (2013) melaporkan, bahwa bahan organik juga dapat menghasilkan humus yang mempunyai KTK jauh lebih tinggi daripada mineral liat. Oleh karena itu semakin tinggi kandungan bahan organik tanah semakin tinggi pula nilai KTK-nya. Dapat dilihat pada Tabel 3, perlakuan tanpa olah tanah (TOT) nilai KTK lebih rendah dibandingkan pada perlakuan olah tanah minimum (OTM) dan olah tanah intensif (OTI), hal ini diduga pada perlakuan tanpa olah tanah memiliki
Tabel 2. Ringkasan uji signifikansi pengaruh sistem olah tanah terhadap beberapa sifat tanah panen tanaman kedelai (Glycine max L.)

\begin{tabular}{lc}
\hline Perlakuan & Panen \\
\hline pH Tanah & tn \\
C-organik & tn \\
Kelembaban & tn \\
Suhu tanah & tn \\
KTK & $*$ \\
\hline
\end{tabular}

Keterangan: $\mathrm{tn}=$ tidak berbeda nyata dan $*=$ berbeda nyata menurut uji BNT pada $\alpha_{0,05}$.

Tabel 3. Uji BNT 5\% olah tanah terhadap kapasitas tukar kation (KTK) pada satu hari sebelum panen tanaman kedelai (Glycine $\max \mathrm{L}$.).

\begin{tabular}{cc}
\hline Perlakuan & Kapasitas Tukar Kation $\left(\mathrm{cmol}(+) \mathrm{kg}^{-1}\right)$ \\
\hline $\mathrm{T}_{0}$ & $10,1 \mathrm{a}$ \\
$\mathrm{T}_{1}$ & $12,0 \mathrm{~b}$ \\
$\mathrm{~T}_{2}$ & $11,6 \mathrm{~b}$ \\
\hline BNT 5\% & 0,50 \\
\hline
\end{tabular}

Keterangan : Angka yang diikuti huruf sama pada kolom yang sama menunjukkan tidak berbeda nyata menurut uji BNT pada $\alpha_{0,05}$. $\mathrm{T}_{0}=$ Tanpa olah tanah, $\mathrm{T}_{1}=$ Olah tanah minimum, $\mathrm{T}_{2}=$ Olah tanah intensif. 
$\mathrm{pH}$ dengan rata-rata 5,2 ; sedangkan pada perlakuan olah tanah minimum (OTM) memiliki $\mathrm{pH}$ dengan ratarata 5,5 dan perlakuan olah tanah intensif (OTI) memiliki $\mathrm{pH}$ dengan rata-rata 5,4.

Pada kebanyakan tanah, ditemukan bahwa pertukaran kation berubah dengan berubahnya $\mathrm{pH}$ tanah. Pada $\mathrm{pH}$ rendah, hanya muatan permanen liat, dan sebagian muatan koloid organik memegang ion yang dapat digantikan melalui pertukaran kation, dengan demikian KTK relatif rendah. Hal ini disebabkan oleh kebanyakan tempat pertukaran kation koloid organik dan beberapa fraksi liat, $\mathrm{H}$ dan mungkin hidroksil-Al terikat kuat, sehingga sukar dipertukarkarkan (Hakim $d k k$., 1986). Faktor iklim merupakan faktor yang paling berperan dalam proses dekomposisi. Di saat temperatur dan kelembaban meningkat, maka proses dekomposisi bahan organik akan semakin cepat. Hal ini juga yang menyebabkan bahwa bahan organik pada tanah tropika di daerah tropis jarang terakumulasi karena faktor iklim sangat optimum bagi aktivitas mikroorganisme dalam melakukan dekomposisi sisa tanaman. Faktor-faktor yang mempengaruhi laju dekomposisi humus adalah pengolahan tanah, temperatur, kelembaban tanah, $\mathrm{pH}$, kedalaman dan aerasi tanah.

Hasil uji korelasi (Tabel 4) terhadap beberapa sifat kimia tanah seperti C-organik, reaksi tanah $(\mathrm{pH})$, kapasitas tukar kation (KTK), kelembaban serta suhu tanah menunjukan bahwa tidak terdapat korelasi dengan biomassa karbon mikroorganisme tanah (C-mik). Artinya, beberapa sifat kimia meliputi C-organik, $\mathrm{pH}$, kapasitas tukar kation (KTK), kelembaban tanah maupun suhu tanah tidak mempengaruhi biomassa

Tabel 4. Ringkasan uji korelasi antara biomassa karbon mikroorganisme tanah (C-mik) dengan $\mathrm{pH}, \mathrm{C}$ organik, kapasitas tukar kation (KTK), kelembaban, dan suhu.

\begin{tabular}{lc}
\hline Perlakuan & $\begin{array}{c}\text { Nilai r biomassa } \\
\text { karbon mikroorganisme tanah } \\
\text { C-mik }\end{array}$ \\
\hline pH Tanah & $-0,18$ tn \\
C-organik & $-0,29$ tn \\
KTK & $-0,05$ tn \\
Kelembaban & 0,30 tn \\
Suhu tanah & $-0,45$ tn \\
\hline
\end{tabular}

Keterangan: $\mathrm{tn}=$ tidak berbeda nyata menurut uji BNT pada $\alpha_{0,05}$. karbon mikroorganisme tanah (C-mik). Hal ini diduga singkatnya waktu penelitian yang digunakan, sehingga bahan organik belum terdekomposisi secara keseluruhan menjadi C-organik dan unsur hara yang lainnya.

\section{KESIMPULAN}

Hasil penelitian ini dapat disimpulkan bahwa biomassa karbon mikroorganisme tanah (C-mik) pada sistem Olah Tanah Konservasi (TOT atau OTM), sama dengan Olah Tanah Intensif (OTI), baik pada masa sebelum olah tanah $\left(\mathrm{W}_{0}\right)$, satu hari setelah olah tanah $\left(\mathrm{W}_{1}\right)$, vegetatif maksimum $\left(\mathrm{W}_{2}\right)$, dan panen $\left(\mathrm{W}_{3}\right)$. Kapasitas tukar kation (KTK) pada perlakuan sistem olah tanah konservasi (TOT atau OTM), lebih rendah dari pada olah tanah intensif (OTI). Tidak terdapat korelasi antara C-organik, kelembaban, suhu, $\mathrm{pH}$, serta KTK dengan biomassa karbon mikroorganisme tanah (C-mik) pada setiap sistem olah tanah.

\section{DAFTAR PUSTAKA}

Arifin, R. 2013. Kapasitas Tukar Kation. http/ blogspot.com. Diakses pada tanggal 1 Mei 2013.

Franzluebber, A. J., D.A. Zuberer and F.M. Hons. 1995. Comparison of Microbiological Methods for Evaluating Quality and Fertility of Soil. Biol. Fertil. Soil. Vol. 19 : 135:140

Hakim, N., M.Y. Nyakpa, A.M. Lubis, S.G. Nugroho, R. Saul, A. Diha, B.H.Go, dan H.H. Bailey. 1986. Dasar-Dasar Ilmu Tanah. Universitas Lampung. Bandar Lampung. $488 \mathrm{hlm}$.

Hasnudi dan Eniza, S. 2004. Rencana Pemanfaatan Lahan Kering untuk Pengembangan Usaha Peternakan Ruminansia dan Usaha Tani Terpadu Di Indonesia. Bogor.

Jenkinson, D. S. And D. S Powlson. 1976. The effect of biocidal treatments on metabolism in soil V. A method for measuring biomass. Soil Biol. Biochem. Vol. 8 : 209-213.

Kirana, A, 2011. Pengaruh sistem olah konservasi dan pemupukan nitrogen jangka panjang terhadap biomassa karbon mikroorganisme tanah (C-mik) dan produksi tanaman jagung (Zea Mays L.) Di tanah Ultisol. Skripsi. Universitas Lampung. Bandar Lampung. 
Nursyamsi, D., J. S. Adiningsih, Sholeh dan A. Adi. 1996. Penggunaan bahan organik untuk meningkatkan efisiensi pupuk $\mathrm{N}$ dan produktivitas tanah Ultisol di Sitiung, Sumbar. $J$. Tanah Trop. Vol. 2 : 26-33.

Rachman, A., S.H. Anderson.C.J.Ganzer, and A.L.Thompson. 2003. Influence of long-term cropping system on soil physical properties relatid to soil erodibility. Soil Sci. Soc. Am. J. Vol. 67: 637-644.

Raguan, E.F. 2009. Pengaruh sistem pengolahan tanah dan pemupukan nitrogen jangka panjang terhadap biomassa karbon mikroorganisme tanah (C-mik) pada pertanaman jagung (Zea mays L.). Skripsi. Fakultas Pertanian Universitas Lampung. Bandar Lampung. 67 hlm.
Utomo, M. 1990. Budidaya Tanpa Olah Tanah Teknologi untuk Pertanian Berkelanjutan. Direktorat Produksi Padi dan Palawija. Departeman Pertanian RI. Jakarta.

Utomo, M. 1995. Kekerasan tanah dan serapan hara tanaman jagung pada olah tanah konservasi jangka panjang. J. Tanah Trop. 1: 1-7. 